\title{
ENDOGENOUS GROWTH MODELS AND STOCK MARKET DEVELOPMENT: EVIDENCE FROM FOUR COUNTRIES
}

\author{
Guglielmo Maria Caporale, South Bank University London \\ Peter G. A Howells, University of East London \\ Alaa M. Soliman, Leeds Metropolitan University
}

February 2003

\begin{abstract}
This paper re-examines the relationship between stock market development and economic growth. It provides a theoretical basis for establishing the channel through which stock markets affect economic growth in the long run. It examines the hypothesis of endogenous growth models that financial development causes higher growth through its influence on the level of investment and its productivity. The empirical part of this study exploits techniques recently developed to test for causality in VARs. The evidence obtained from a sample of four countries suggests that investment productivity is the channel through which stock market development enhances the growth rate in the long run.
\end{abstract}

Keywords: Financial Development, Endogenous Growth, Stock Market, Channel of Transmission, Causality Testing in VARs

JEL classification: C12, C32, O16

Corresponding author: Professor Guglielmo Maria Caporale, Centre for Monetary and Financial Economics, South Bank University, 103 Borough Road, London SE1 OAA, UK. Tel: +44 (0)20 7815 7012. Fax: +44 (0)20 7815 8226. E-mail: g.m.caporale@sbu.ac.uk 


\section{Introduction}

Several theoretical and empirical papers such as Levine (1991), Levine and Zervos (1995), Demirguc-Kunt (1994), and Demirguc-Kunt and Levine (1996) have suggested that stock market development affect economic growth in developing countries. The common problem with these studies, however, is that there is no discussion of the channels through which stock markets can stimulate economic growth.

In traditional growth theory, the growth rate is a positive function of exogenous technical progress. However, financial development is not related to economic growth, but to physical capital per worker (Pagano 1993). On the other hand, endogenous growth models show that economic growth performance is related to financial development, technology and income distribution. Greenwood and Jovanovic (1990) argued that income per capita helps determine membership in an information-processing intermediary that in turn improves investment decisions and economic growth. They incorporated the role of financial factors in models of endogenous growth to formalise the interactions between financial markets and economic growth. Due to the advances in the endogenous growth literature, recent models have been trying to identify the mechanism through which financial markets influence economic growth. Various channels have been suggested. Firstly, financial markets can affect economic growth through efficient resource allocation. King and Levine (1993) proposed a model in which innovation activities serve as the engine of growth. A higher rate of successful innovations results in a higher growth rate of productivity. In the absence of financial markets, one might invest in projects that can be promptly liquidated, instead of investing in assets that are more productive but financially illiquid. Markets can provide individuals with less risky and liquid productive investments (Levine, 1993). Secondly, financial markets can influence 
economic growth through the information channel. For example, Holmstrom and Tirole (1993) argue that stock markets function as a monitor of managerial performance because the stock price incorporates performance information that cannot be extracted from a firm's current or future data. A poorly performing management may become the target for a take-over. Thus, the information that is reflected in a firm's share price is important for structuring managerial incentives to build up a firm's productivity, and hence economic growth in aggregate.

By contrast, endogenous growth models focus on the relationship between financial development and long-run economic growth, emphasising that productivity growth is most likely to be the channel of transmission from financial development to economic growth. However, previous studies by Bencivenga and Smith (1991) and Levine (1991) still do not identify the unique functions of different financial markets, and their effects on economic growth. There is no attempt to distinguish the roles played by different financial markets, such as banks, bond markets, insurance companies, and stock markets in the relationship between financial markets and economic growth. In previous studies, banks and insurance companies would normally be regarded as intermediaries rather than markets; also, the role of stock markets in economic growth and the identification of the channels through which stock markets affect growth is ignored.

\section{Investment, stock market, and economic growth}

Within the endogenous growth literature, recent theoretical studies have focused on the links between endogenous growth and financial markets. Bencivenga and Smith (1991) and Levine (1991) were among the first to propose endogenous growth models

to identify the channels through which financial markets affect long-run economic 
growth. Both papers emphasised that financial markets help diversify agents' liquidity and investment risk, attract more savings into productive investment and prevent the premature withdrawal of physical capital invested in the long-term projects. With the existence of financial markets more capital can be kept in productive investments, which raises the rate of economic growth.

King and Levine (1993) suggested another approach to identifying the channel of transmission between finance and growth. Their model identified innovation as the engine of growth. Financial markets evaluate the potential innovative projects, finance the most promising ones and monitor the carrying out of the investment. That is, financial markets help the function of efficient resource allocation. Therefore, an economy with well-functioning financial markets will experience a higher growth rate of productivity (Demetriades and Hussein, 1996).

In a modern economy banks and stock markets constitute a major part of the financial system. Although they may perform different roles in the process of economic development, their uniqueness is hardly emphasised within the framework of economic growth. The channel emphasised by King and Levine (1993) cannot distinguish between the roles of stock markets and banks. As far as physical accumulation is concerned, both stock markets and banks provide sources of external financing for firms. For the function of resource allocation, both stock markets and banks create information to guide the allocation of resources. They differ only in the way the information is transmitted. Information in stock markets is contained in equity prices, while loan managers collect that in banks. Dow and Gorton (1995) presented a model that argued that if the main role of the stock market is to signal information for evaluation, financing, and monitoring, banks may be equally effective at efficient resource allocation. Although some papers had studied the effect of stock 
market on social welfare (see Bresnahrah, Milgrom, and Paul 1992, Kihlstrom and Matthews, 1990), to the best of our knowledge no study has ever tried to link empirically stock markets and economic growth through volume andor investment productivity.

Another perspective on the relationship between financial development and economic growth in endogenous growth models is concerned with financial markets, savings, investments, and growth. The argument is that financial markets will raise savings, investment and hence the growth rates. The stock market is supposed to encourage savings by providing households with an additional instrument which may better meet their risk preferences and liquidity needs. In a well-developed capital market, share ownership provides individuals with a relatively liquid means of sharing risk in investment projects. There is also considerable evidence on the extent to which these markets are playing a role in allocating capital to the corporate sector and the beneficial effects for the rest of the economy. Although the structure of corporate finance varies widely among the developing countries the use of equity finance by the corporate sector has been significant. During the 1980s, as a share of net investment expenditures, equity funds exceeded debt finance, or internally generated funds, in countries like Korea, and Thailand (Singh and Hamid 1993). As Mayer (1987) shows, this contrasts sharply with the corporate finance pattern in industrial countries, which in general rely much more on internally generated funds. The evidence indicates that the stock market does not perform this savings function at all well.

Thus, more recent research on the role of the stock market in an economy has emphasised the role of a developed stock market, which enhances the efficiency of investment, in turn leading to higher economic growth. Therefore, stock markets can 
enhance economic growth through investment productivity rather than the savings function.

In this paper we test this hypothesis empirically by examining the causal linkages between these variables in four developing countries, i.e. Chile, Korea, Malaysia and the Philippines. We employ recently developed tests for causality in VARs which result in valid statistical inference even in the presence of unit roots (see Toda and Yamamoto, 1995). The rest of the paper is organised as follows. Section 2 discusses some relevant econometric issues that arise when testing for causality. Section 3 presents the empirical evidence. Section 4 offers some concluding remarks.

\section{Econometric Methodology}

Testing for causality in possibly unstable VARs with the possibility that cointegration also exists was first addressed by Sims, Stock and Wallace (1990) in a trivariate VAR, and by Toda and Phillips (1993) for systems of higher dimension. They showed that, in general, Wald test statistics for noncausality in an unrestricted VAR would have a nonstandard limit distribution. When estimating a VAR in le vels, a Wald test will have a limiting $\chi^{2}$ distribution only if there is "sufficient" cointegration, which depends on the presence and the location of the unit roots in the VAR, information which is normally not easy to obtain (see Toda and Phillips, 1993). However, sequential testing strategies such as the one put forward by Toda and Phillips (1993), where the cointegration rank has to be determined as a first step, are potentially subject to severe pretesting bias.

Toda and Yamamoto (1995) have suggested an alternative approach to causality testing which has the advantage of not requiring pretesting for the cointegration rank, 
and still produces valid statistical inference. ${ }^{1}$ This is the technique we use below for the empirical analysis. The basic idea is to artificially augment the correct order, $\mathrm{K}$, of the VAR by the maximal order of integration, say $\mathrm{T}_{\max }$. The augmented $\left(\mathrm{K}+\mathrm{T}_{\max }\right)$ is then estimated, and Wald tests for linear or non-linear restrictions are carried out on the first $\mathrm{K}$ coefficient matrix as follows:

Consider the following VAR:

$Z_{t}=\Phi+\Phi t+\Pi_{1} Z_{t-1}+\ldots+\Pi_{k} Z_{t-k}+E_{t}, t=1, . . T$

where $E_{t} \sim N(0, \Omega)$

Economic hypotheses can be expressed as restrictions on the coefficients of the model as follows:

$H_{0}: f(\pi)=0$

where $\pi=\operatorname{vec}(P)$ is a vector of parameters from model (1), $P=\left[\Pi_{1}, \ldots, \Pi_{k}\right]$, and $\mathrm{f}($. is a twice continuously differentiable m-vector valued function with $F(\phi)=\partial f(\phi) / \partial \phi^{\prime}$ and $\operatorname{rank}(\mathrm{F}())=.\mathrm{m}$.

Assume that the maximum order of integration which is expected to characterise the process of interest is at most two, i.e. $\mathrm{d}_{\max }=2$. Then, in order to test the hypothesis (2), one estimates the following VAR by OLS:

$Z_{t}=\hat{\Phi}_{0}+\hat{\Phi}_{1} t+\hat{\Pi}_{1} Z_{t-1}+\ldots+\hat{\Pi}_{k} Z_{t-k}+\hat{\Pi}_{k+1} Z_{t-k-1} \ldots+\hat{\Pi}_{p} Z_{t-p}+\hat{E}_{t}$

where $p \geq k+d_{\max }=k+2$, i.e. at least two more lags than the true lag length $\mathrm{k}$ are included. The parameter restriction (2) does not involve the additional matrices

\footnotetext{
${ }^{1}$ See Caporale and Pittis (1999) for further details and a discussion of other methods.
} 
$\Pi_{k+1}, \ldots, \Pi_{p}$, since these consist of zeros under the assumption that the true lag length is $\mathrm{k}$.

Equation (3) can be written in more compact notation as follows:

$$
Z_{t}=\hat{\Phi} \tau_{t}+\hat{P} x_{t}+\hat{\Psi} y_{t}+\hat{E}_{t}
$$

where:

$\hat{\Phi}=\left[\hat{\Phi}_{0}, \hat{\Phi}_{1}\right]$

$\tau_{t}=[1, t]$

$x_{t}=\left[Z_{t-1}^{\prime}, \ldots, Z_{t-k}^{\prime}\right]^{\prime}$

$y_{t}=\left[Z_{t-k-1}^{\prime}, \ldots, Z_{t-p}^{\prime}\right]^{\prime}$

$\hat{P}=\left[\hat{\Pi}_{1}, \ldots, \Pi_{k}\right]$

$\hat{\Psi}=\left[\hat{\Pi}_{k+1}, \ldots, \hat{\Pi}_{p}\right]$

or, in the usual matrix notation

$Z^{\prime}=\hat{\Phi} T+\hat{P} X^{\prime}+\hat{\Psi} Y^{\prime}+\hat{E}^{\prime}$

where $X=\left[x_{1}, \ldots x_{T}\right]^{\prime}$ and so on.

One can then construct the following Wald statistic $\mathrm{W}_{2}$ to test the hypothesis (2):

$W_{2}=f(\hat{\phi})^{\prime}\left[F(\hat{\phi})\left\{\hat{\Sigma}_{E} \otimes\left(X^{\prime} Q X\right)^{-1}\right\} F(\hat{\phi})^{\prime}\right]^{-1} f(\hat{\phi})$

where $\hat{\Sigma}_{E}=T^{-1} \hat{E} \hat{E}^{\prime}, Q=Q_{\tau}-Q_{\tau} Y\left(Y^{\prime} Q_{\tau} Y\right)^{-1} Y^{\prime} Q_{\tau}$ and $Q_{\tau=} I_{T}-T\left(T^{\prime} T\right)^{-1} T$.

Toda and Yamamoto's (1995) theorem 1 (pp. 234235) proves that the Wald statistic (5) converges in distribution to a $\chi^{2}$ random variable with $\mathrm{m}$ degrees of freedom, regardless of whether the process $Z_{4}$ is stationary, $I(1), I(2)$, possibly around a linear trend, or whether it is cointegrated.

This method also requires some pretesting in order to determine the lag length of the process. Sims et al (1990) showed that lag selection procedures, commonly 
employed for stationary VARs, which are based on testing this significance of lagged vectors by means of Wald (or LM or LR) tests, are also valid for VARs with I(1) processes which might exhibit cointegration. Toda and Yamamoto (1995) extended their analysis and proved that the asymptotic distribution of a Wald of Likelihood Ratio test for the hypothesis that the lagged vector of order $\mathrm{p}$ is equal to zero is $\chi^{2}$, unless the process is Markovian and I(2).

\section{Empirical analysis}

\section{a) Data}

The selected countries are Chile, Korea, Malaysia and Philippines. The selection criterion was to include countries that have at least fifty continuos quarterly observations. The model is estimated using quarterly data for the period $1979 \mathrm{q} 1$ to 1998q4. Following Gelb (1989), and Levine (1991) the level of investment is measured by the ratio of gross fixed capital formation to nominal GDP, LI. Investment productivity is proxied by the ratio of the real change of GDP to the real level of total investment, LPI. For stock market development, we use two standard indicators: 1) the market capitalisation ratio, which equals the value of listed shares divided by GDP. 2) The value traded ratio, which equals the total value of shares traded on the stock exchange divided by GDP.

Following standard practice in the cross-sectional literature, we use GDP in levels as a measure for economic development. As in Demetriades and Hussein (1996), this variable is measured in domestic currencies since the purpose of this study is not so much to compare growth across countries but to look at its trend over time in each country. The data source for stock market development variables is the Emerging Market Data Base (EMDB, 1998), and for the financial development variables it is the IMF publication International Financial Statistics (1998). 


\section{b) Empirical results}

First of all, we carried out unit root tests, which indicate that all series are integrated of order one (I(1)), and hence follow stochastic trends (see Table 1). Next we estimated two sets of trivariate VAR including stock market measures, investment and output growth for each of the four countries under study. The first set includes stock market development measured by market capitalisation, investment measured by level of investment and the level of GDP, the second set includes stock market development measured by share value traded ratio, investment measured by productivity investment and the level of GDP. In order to determine the lag length, we started by estimating a VAR (4) and then dropped one lag at a time. The AIC and SIC were used for selecting the lag-length of the $\mathrm{VAR}^{2}$. Moreover, misspecification tests were carried out for serial correlation, normality, and ARCH structure in the residuals of the VAR. The results are reported in Table 2.

The next step was to augment the VAR by the maximum order of integration in the series (namely, one) and test for non-causality zero restrictions on the parameters of the original VAR by carrying out Wald tests on the first $\mathrm{K}$ coefficient matrix (see Toda and Yamamoto, 1995). The results from the non-causality trivariate test on the causal links between stock markets investment and economic growth are presented in Table 3.

The null hypothesis is that there is no causality among the variables concerned. The results show that in Chile the null hypothesis of non-causality among market capitalisation, total level of investment, and economic growth cannot be rejected at the 5 and 10 percent significance levels. However, in the case of Chile there is no

evidence of a causal linkage between stock market development (represented by 
market capitalisation), and economic growth, when one focuses on level of investment as the channel through which stock markets affect economic growth.

Wald tests were also carried out for the null hypothesis of non-causality among stock market development (measured by market capitalisation), total level of investment, and economic growth for Korea. Unlike in Chile, the stock market is found to have a causal impact on economic growth, when one focuses on the total level of investment as the channel through which stock markets might affect economic growth (the null hypothesis can be rejected at the 5 percent significance level). In the case of Malaysia, the stock market is found to have a causal effect on economic growth through the total level of investment, when market capitalisation is used as the measure for stock market development. By contrast, in the case of the Philippines Wald tests did not detect a causality linkage between stock market development and economic growth, when the total level of investment is considered as the possible channel through which stock markets affect economic growth.

Concerning the alternative measure of investment and stock market development (i.e. investment productivity and share value traded ratio), Wald tests indicate that stock market development measured by share value traded ratio has a causal impact on economic growth in all four cases (Chile, Korea, Malaysia and Philippines). When investment productivity is considered as the possible transmission channel, the null hypothesis of non-causality cannot be rejected at the 5 percent significance level in all four cases (see Table 3).

We also test the hypothesis of non-causality between stock market development and investment. A causal link is only found in Malaysia, when considering market capitalisation and level of investment as measures for stock market development and

\footnotetext{
${ }^{2}$ To select the optimal lag length of the VAR, these criteria for model choice are necessary but not sufficient.
} 
investment respectively. Turning to the second stock market development and investment measures, causality tests indicates that the share value traded ratio causes productivity investment in all four countries under study. The result is consistent with the findings by Levine and Zervos (1995). Using a cross-section analysis, they found that there is strong linkage among stock market, productivity investment, and economic growth.

Overall the results from the Wald tests are consistent with the endogenous growth literature. Levine (1991) argues that stock markets can affect productivity investment by raising the resources devoted to firms. This does not necessarily depend on externalities. By increasing the liquidity of firm investment, reducing productivity risk, and improving firm efficiency, firms share will be better valued hence, increasing the volume and productivity of investment in the long run. However, the finding supports the argument that stock market performance enhances economic growth through increasing the efficiency of investment, which in turn increases the productivity in the firm level and in the economy in aggregate.

\section{Conclusion}

This paper has examined the hypothesis that stock market development affects economic growth through its impact on investment. In the empirical analysis we have considered four countries, and utilised an appropriate econometric technique due to Toda and Yamamoto (1995) to test for the causality linkage between stock markets, investment, and economic growth. This approach has the advantage of not requiring pretesting for the cointegration properties of the system (which can introduce biases), and of resulting in standard asymptotic and valid statistical inference. In line with the recent endogenous growth models for financial development, we find that investment 
productivity is the channel through which stock markets enhance the growth rate in the long run.

The results are also consistent with the findings by Levine and Zervos(1995) and the argument by Demirguc-Kunt(1994) that stock markets can give a big boost to economic development. In addition, though, this study shows that stock market development enhances economic growth through its impact on investment productivity in the long run. The results also consistent with Leigh's (1997) argument that well-functioning stocks market can perform its allocative functions through the pricing of shares. An efficient pricing process will reward the well-managed and profitable firms by valuing their shares more highly than those of unsuccessful and unprofitable firms. This mechanism lowers the cost of capital and hence ensures a greater allocation of new investment resources, and in aggregate will enhance economic growth. Thus, a general conclusion of this study might be that a wellfunctioning stock market is vital in promoting economic growth in less-developed countries. 


\section{References}

Bencivenga, V.R. and B.D.Smith., (1991),"Financial Intermediation and Endogenous Growth", Review of Economic Studies, Vol.58, pp.195-209.

Bresharan, T., Milgrom, P., and Paul, J., (1992),"The Real Output of the Stock Exchange", University of Chicago Press, Chicago, pp.195-216.

Caporale, G.M. and N. Pittis (1999), "Efficient estimation of cointegrating vectors and testing for causality in vector autoregressions", Journal of Economic Surveys, vol. 13, issue no.1, pp. $1-35$.

Demetriades, P. and Hussein K. (1996), "Does Financial Development Cause Economic Growth: Time-Series Evidence from 16 countries", Journal of Development Economics, Vol.51, pp. 387-411.

Demirguc-Kunt, A. (1994),"Developing Country Capital Structure and Emerging Stock Markets", Policy Research Working Paper, WPS, No 933.

Demirguc-Kunt, A and Levine, R. (1995),"Stock Markets, Corporate Finance, and Economic Growth: An Overview", Working Paper, World Bank, No 1389.

Dow, J, and Gorton, G., (1995), "Stock Market Efficiency and Economic Efficiency: Is There a Connection?”, NBER Working Paper, No.5233.

Engle, R.F. (1982), "Autoregressive conditional heteroscedasticity with estimates of the variance of United Kingdom inflation", Econometrica, 50, 987-1008.

Gelb A.H., (1989),"Financial Policies, Growth, and Efficiency", Policy Planning, and research Working Paper, No.202, Woddbank

Greenwood, J. and B. Jovanovic, (1990), "Financial Development, Growth and the Distribution of Income", Journal of Political Economy, Vol. 98, 1076-1107.

International Finance Corporation (IFC), 1979-1998, Emerging Stock Markets Factbook, Washington D.C.

Intemational Monetary Fund, Intemational Financial Statistics (Various Years), Washington D.C.

Holmstrtom, B, and Tirole, J., (1993), "Market Liquidity and Performance Monitoring", Journal of Political Economy, Vol. 101, pp.768-709.

Kihlstrom, R, and Matthews, P., (1990), "Managerial Incentives in an Entrepreneurial Stock Market Model”, Journal of Financial Intermediation, Vol1, pp.57-59.

King, R. G. and R. Levine, (1993), "Finance and Growth: Schumpter Might be Right", Quarterly Journal of Economics, vol.108, pp.717-737

Leigh,L. (1997)" Stock Market Equilibrium and Macroeconomic Fundamentals" IMF Working Paper, WP/ 79/ 15 
Levine, R, (1991), "Stock Markets, Growth and Tax Policy", Journal of Finance, Vol.64, pp. 1445-1465.

Levine, R., (1993), "Financial Structures and Economic Development" Revista de Analisis Economico, Vol.8, pp.113-129.

Levine, R., and Zervos, S. (1995), "Stock Market Development and Long-Run Growth", World Bank Economic Review, Vol.182, No 4, pp.942-963.

Mayer, C. (1987).'New Issues in Corporate Finance", Discussion Paper, Centre for Economics and Policy Research, London, No.181.

Pagano, M., (1993), "Financial Markets and Growth: an Overview", European Economic Review, Vol. 37, 613-622

Sims C. A, Stock J H and Wallace M.W. (1990), "Inference in linear time series models with some unit roots", Econometrica, 58, 1, pp.113-44.

Singh, A. and Hamid, J. (1993). "Corporate financial structure in developing countries", Technical Papers, No.1, Economics Department, IFC, World Bank, Washington.

Stock, J.M. (1994), "Unit Roots, Structural Break and Trends", in Handbook of Econometrics, eds R.F.Engle and D.McFadden, North Holland, pp.2738-841.

Toda, H.Y. and P.C.B.Phillips. (1993), "Vector autoregression and causality", Econometrica, 61, 6, pp.1376-1393.

Toda, H.Y. and T. Yamamoto. (1995), "Statistical inference in vector autoregressions with possibly integrated processes", Journal of Econometrics, Vol.66, pp.225-250. 
Table 1: Unit root tests

\begin{tabular}{|c|c|c|c|c|c|}
\hline \multirow[t]{2}{*}{ countries } & \multicolumn{5}{|c|}{$\underline{\mathrm{ADF} \text { with trend }}$} \\
\hline & I & PI & X 1 & $\mathrm{X} 2$ & $\mathrm{Y}$ \\
\hline Chile & -1.43 & -1.20 & -0.16 & -0.13 & -1.45 \\
\hline Korea & $4.40^{*}$ & -1.38 & -2.04 & -3.86 & -1.79 \\
\hline Malaysia & -2.34 & -3.02 & -2.16 & -2.20 & -2.85 \\
\hline Philippines & $4.18^{*}$ & $-4.18^{*}$ & -3.12 & -2.24 & -3.42 \\
\hline $\begin{array}{ll}- & \text { Irefe } \\
- & \text { PI re } \\
- & \text { x1 re } \\
- & \text { x2 re } \\
- & \text { y ref } \\
- & \text { Iar }\end{array}$ & $\begin{array}{l}\text { evel of } \\
\text { e produc } \\
\text { arket cay } \\
\text { are value } \\
\text { P in lev }\end{array}$ & $\begin{array}{l}\text { vestment } \\
\text { vity of in } \\
\text { alisation. } \\
\text { raded rati }\end{array}$ & ment. & & \\
\hline
\end{tabular}

Table 2: Selection of the order of trivariate VAR $(\mathrm{k})$

\begin{tabular}{|c|c|c|c|c|c|c|c|c|c|}
\hline \multirow[t]{2}{*}{ Countries } & \multicolumn{4}{|l|}{$\underline{\mathrm{AIC}}$} & \multicolumn{4}{|c|}{$\underline{\mathrm{SIC}}$} & \multirow{2}{*}{$\begin{array}{c}\text { Optimal } \\
\left(\mathrm{K}^{*}\right)\end{array}$} \\
\hline & 1 & 2 & 3 & 4 & 1 & 2 & 3 & 4 & \\
\hline Chile & $\begin{array}{l}114.3 \\
(124.1)\end{array}$ & $\begin{array}{c}125.1 \\
(159.5)\end{array}$ & $\begin{array}{l}141.8 \\
(132.5)\end{array}$ & $\begin{array}{r}132.1 \\
(127.1)\end{array}$ & $\begin{array}{c}109.2 \\
(103.1)\end{array}$ & $\begin{array}{l}113.6 \\
(109.3)\end{array}$ & $\begin{array}{c}123.4 \\
(116.7)\end{array}$ & $\left.{ }^{1} 124.2\right)$ & \\
\hline Korea & $\begin{array}{l}131.2 \\
(146.7)\end{array}$ & $\begin{array}{l}152.2 \\
(151.5)\end{array}$ & $\begin{array}{r}161.3 \\
(158.6)\end{array}$ & $\begin{array}{r}169.1 \\
(161.1)\end{array}$ & $\begin{array}{r}116.6 \\
(113.9)\end{array}$ & $\begin{array}{c}124.9 \\
(125.8)\end{array}$ & $\begin{array}{c}134.9 \\
(134.3)\end{array}$ & $\begin{array}{c}152.3 .1 \\
(131.8)\end{array}$ & 4 \\
\hline Malaysia & $\begin{array}{l}162.3 \\
(128.1)\end{array}$ & $\begin{array}{r}171.8 . \\
(132.7)\end{array}$ & $\begin{array}{r}176.1 \\
(137.6)\end{array}$ & $\begin{array}{r}186.8 \\
(145.1)\end{array}$ & $\begin{array}{c}141.1 \\
(116.9)\end{array}$ & $\begin{array}{c}152.2 \\
(122.4)\end{array}$ & $\begin{array}{c}156.3 .1 \\
(123.8)\end{array}$ & $\begin{array}{c}164.1 \\
(131.6)\end{array}$ & 4 \\
\hline Philippines & $\begin{array}{l}136.1 \\
(102.3) \\
\end{array}$ & $\begin{array}{r}138.2 \\
(116.5) \\
\end{array}$ & $\begin{array}{r}146.9 \\
(131.9) \\
\end{array}$ & $\begin{array}{r}141.4 \\
(126.5) \\
\end{array}$ & $\begin{array}{c}113.4 \\
(91.4)\end{array}$ & $\begin{array}{l}227.1 \\
(94.2)\end{array}$ & $\begin{array}{c}131.5 \\
(106.3)\end{array}$ & $\begin{array}{c}129.1 \\
(112.2)\end{array}$ & 3 \\
\hline
\end{tabular}

- $\quad$ AIC and SIC stand for Akaike and Schwartz information criteria respectively.

- $\quad \mathrm{K}^{*}$ is the selected order of the VAR.

- $\quad$ Note: in case of contradicting results between AIC and SIC, we tend to use AIC results as suggested by Stock (1994).

- $\quad$ Results in brackets are for the second VAR. 
Table 2 (continued): pvalues for misspecification tests for the the first set VAR $(\mathrm{K}), \mathrm{K}=\mathrm{K}^{*}$

\begin{tabular}{l} 
Countries \\
\hline Chile
\end{tabular}

Table 2 (continued): pvalues for misspecification tests for the second set VAR $(\mathrm{K}), \mathrm{K}=\mathrm{K} *$

\begin{tabular}{|c|c|c|c|c|c|c|c|c|c|}
\hline \multirow[b]{2}{*}{ Countries } & \multicolumn{3}{|c|}{ AR (4) } & \multicolumn{3}{|c|}{ NORM } & \multicolumn{3}{|c|}{ ARCH (4) } \\
\hline & Y & $\mathrm{X} 2$ & PI & $\mathrm{Y}$ & X2 & PI & $\mathrm{Y}$ & X2 & PI \\
\hline Chile & 2.31 & 1.62 & 2.32 & 241 & 2.21 & 1.98 & 2.34 & 1.32 & 0.72 \\
\hline Korea & 1.52 & 2.51 & 2.11 & 3.62 & 3.21 & 2.62 & 0.72 & 1.14 & 1.32 \\
\hline Malaysia & 3.26 & 3.31 & 2.64 & 2.11 & 1.62 & 3.13 & 0.75 & 1.51 & 0.82 \\
\hline Philippines & 2.51 & 1.14 & 2.82 & 2.31 & 2.51 & 3.62 & 0.25 & 0.37 & 0.41 \\
\hline $\begin{array}{ll}- & \text { AR ((4) } \\
& \text { test for } \\
& \text { have an } \\
- & \text { For the P } \\
- & \text { One aste } \\
- & \text { AIC and }\end{array}$ & $\begin{array}{l}\text { in stre } \\
\text { ppines } \\
\text { indice }\end{array}$ & $\begin{array}{l}\text { nge M } \\
\text { f the } r \\
\text { cture. } \\
\text { the ord } \\
\text { es that } \\
\text { 6r Aka }\end{array}$ & $\begin{array}{l}\text { ier test } \\
\text { als, and } \\
\text { the VAI } \\
\text { st is sig } \\
\text { ad Schw }\end{array}$ & $\begin{array}{l}\text { relatio } \\
\text { is the }\end{array}$ & $\begin{array}{l}\text { to the } \\
\text { gle }(1982\end{array}$ & $\begin{array}{l}\text { urth ord } \\
\text { test for }\end{array}$ & $\begin{array}{l}\text { residuals } \\
\text { hypothes }\end{array}$ & $\begin{array}{l}\text { NORI } \\
s \text { that }\end{array}$ & $\begin{array}{l}\text { the } \mathrm{Ja} \\
\text { residua }\end{array}$ \\
\hline
\end{tabular}


Table 3: Trivariate Causality Tests

\begin{tabular}{|c|c|c|c|c|}
\hline \multirow{2}{*}{ Countries } & $\underline{X 1 / I / Y}$ & \multicolumn{3}{|c|}{$\underline{\mathrm{X} 2 / \mathrm{PI} / \mathrm{Y}}$} \\
\hline & $X 1 \Rightarrow Y$ & $\mathrm{X} 1 \Rightarrow \mathrm{I}$ & $X 2 \Rightarrow Y$ & $\mathrm{X} 2 \Rightarrow \mathrm{PI}$ \\
\hline Chile & 1.27 & 2.93 & $6.62^{*}$ & $9.45^{*}$ \\
\hline Korea & $7.91 *$ & 2.29 & $7.15^{*}$ & $8.09^{*}$ \\
\hline Malaysia & $7.07 *$ & $5.89 *$ & $6.05^{*}$ & $7.10^{*}$ \\
\hline Philippines & 0.13 & 0.19 & $14.42 *$ & 4.77* \\
\hline
\end{tabular}

Note:

- An asterisk indicates significance at 5\% level.

The estimated model in the trivariate VAR is:

$$
Z_{t} \equiv\left[\begin{array}{c}
x_{t} \\
y_{t} \\
w_{t}
\end{array}\right]=\beta+\beta_{1} t+\sum_{i=1}^{k+1} A_{i}+Z_{t-i}+E_{t} \quad A_{i}=\left[\begin{array}{l}
\alpha_{11} \alpha_{12} \alpha_{13} \\
\alpha_{21} \alpha_{22} \alpha_{23} \\
\alpha_{31} \alpha_{32} \alpha_{33}
\end{array}\right]
$$

